\title{
Effect of GH and/or testosterone deficiency on the prostate: an ultrasonographic and endocrine study in GH-deficient adult patients
}

Annamaria Colao, Stefano Spiezia ${ }^{1}$, Carolina Di Somma, Paolo Marzullo, Gaetana Cerbone, Rosario Pivonello, Antongiulio Faggiano and Gaetano Lombardi

Department of Clinical and Molecular Endocrinology and Oncology, 'Federico II' University of Naples, Naples and ${ }^{1}$ Echo-guided Surgery Unit 'S. Maria del Popolo degli Incurabili' Hospital, Naples, Italy

(Correspondence should be addressed to A Colao, Department of Molecular and Clinical Endocrinology and Oncology, University 'Federico II' of Naples, Via S. Pansini 5,80131 Naples, Italy; Email: colao@unina.it)

\begin{abstract}
Background: The role of IGF-I in prostate development is currently under thorough investigation since it has been claimed that IGF-I is a positive predictor of prostate cancer.

Objective: To investigate the effect of chronic GH and IGF-I deficiency alone or associated with testosterone deficiency on prostate pathophysiology in a series of patients with hypopituitarism. Design: Pituitary, androgen and prostate hormonal assessments and transrectal prostate ultrasonography (TRUS) were performed in 30 men with adulthood onset GH deficiency (GHD) and 30 agematched healthy controls, free from previous or concomitant prostate disorders.

Results: Plasma IGF-I levels were significantly lower in GHD patients than in controls (Pearson's coefficient $P<0.0001$ ). At study entry, 6 of the 13 hypogonadal patients and 7 of the 17 eugonadal patients had plasma IGF-I below the age-adjusted normal range. At study entry, testosterone levels were low in 13 patients (mean \pm s.E.M., $3.8 \pm 1.0 \mathrm{nmol} / \mathrm{l}$ ) while they were normal in the remaining 17 $(19.4 \pm 1.4 \mathrm{nmol} / \mathrm{l})$. No difference in prostate-specific antigen (PSA), and PSA density was found between GHD patients (either hypo- or eugonadal) and controls, while free PSA levels were significantly higher in eugonadal GHD than in controls $(0.4 \pm 0.04 \mathrm{vs} 0.2 \pm 0.03 \mu \mathrm{g} / \mathrm{l} ; P<0.01)$.

No difference in antero-posterior prostate diameter and transitional zone volume (TZV) was observed among groups, while both transverse and cranio-caudal diameters were significantly lower in hypogonadal $(P<0.01)$ and eugonadal GHD patients $(P<0.05)$ than in controls. Prostate volume (PV) was significantly lower in hypogonadal GHD patients $(18.2 \pm 3.0 \mathrm{ml})$ and eugonadal GHD patients $(22.3 \pm 1.6 \mathrm{ml})$, than in controls $(25.7 \pm 1.4, P<0.05)$. The prevalence of prostate hyperplasia $(\mathrm{PV}>30 \mathrm{ml}$ ) was significantly lower in hypogonadal and eugonadal GHD patients, without any difference between them $(15.3 \%$ and $5.8 \%)$, than in controls $(43.3 \%)\left(\chi^{2}=6.90, P=0.005\right)$. No difference was found in PV between patients with normal or deficient IGF-I levels both in the hypogonadal group $(19.9 \pm 4.7$ vs $17.3 \pm 4.0 \mathrm{ml})$ and in the eugonadal group $(22.6 \pm 2.3$ vs $21.8 \pm 2.5 \mathrm{ml})$. When controls and patients were divided according to age $(<60$ years and $>60$ years), PV was significantly lower in hypogonadal GHD patients aged below 60 years than in agematched controls $(P<0.01)$ or eugonadal GHD patients $(P<0.01)$, without any difference between controls and eugonadal GHD patients. Controls aged above 60 years had significantly higher PV than both hypogonadal and eugonadal GHD patients $(P<0.01)$. Calcifications, cysts or nodules were found in $56.7 \%$ of patients and in $50 \%$ of controls $\left(\chi^{2}=0.067, P=0.79\right)$. In controls, but not in GHD patients, PV and TZV were correlated with age $(r=0.82, r=0.46, P<0.0001$ and $P<0.01$ respectively). PV was also correlated with GH $(r=-0.52, P=0.0026)$, IGF-I $(r=-0.62$, $P=0.0002)$ and IGF-binding protein 3 (IGFBP-3) levels $(r=-0.39, P=0.032)$ but neither with testosterone or dihydrotestosterone (DHT) levels. In GHD patients TZV but not PV was correlated with age $(r=0.58, P=0.0007)$ and neither TZV nor PV were correlated with GH, IGF-I or IGFBP-3 levels.

Conclusions: Chronic GH deficiency in adulthood causes a decrease in prostate size, mostly in patients with concomitant androgen deficiency and age below 60 years, without significant changes in the prevalence of structural prostate abnormalities.
\end{abstract}

European Journal of Endocrinology 143 61-69 


\section{Introduction}

Testosterone and its more potent 5 - $\alpha$-reduced metabolite, dihydrotestosterone (DHT) are the most important determinants of physiological development and growth of the prostate (1). In particular, DHT is considered as the leading factor in stimulating prostate benign and malignant disorders (1), although occult prostate carcinoma has been found also in patients with low testosterone levels (2). However, great attention has been recently given to the role played by insulin-like growth factors (IGFs)-I and -II and IGF-binding proteins (IGFBPs) on the prostate (3). Both IGFs possess direct mitogenic effects on several tissues, including normal and tumoral prostate epithelial cells and their implication in prostate cancer has been suggested as well (4-6). Moreover, IGF-I was found to be directly correlated while IGFBP-3 resulted inversely correlated to prostate cancer risk (5). Changes in each of the IGF-I system, IGFs and their receptors, IGFBPs and IGFBP proteases, have been reported in prostate cancer (7). Although normal prostatic epithelial cells, which are the cells originating prostate cancer, neither synthesize nor secrete significant amounts of IGF-I or IGF-II, they respond to the mitogenic stimulation of IGFs (8). IGFI seems to be implicated in promoting overgrowth of the prostate: specific binding sites for IGF-I are present in prostatic tissue from patients with benign prostatic hyperplasia $(\mathrm{BPH})$, and androgen deprivation by gonadotropin-releasing hormone analogue treatment increases their binding capacities and seems to modify IGF-I receptors localization in the prostatic epithelium (9). The hypertrophic effect of IGF-I on the prostate has also been recently observed in acromegalic patients $(10,11)$. Prostate hypertrophy and increased prevalence of prostate abnormalities were found in acromegalic patients as compared with age-matched controls even in younger ones not expected to have agedependent prostate diseases $(10,11)$. Suppression of circulating growth hormone $(\mathrm{GH})$ and IGF-I after treatment with octreotide induced a significant reduction of prostate volume, suggesting a direct relationship between the GH-IGF-I axis and prostate size (10).

No data are presently available on prostate size and disease in adult patients with GH deficiency (GHD). GHD in adults is a complex syndrome as it is associated with changes in bone turnover and body composition, impairment in lipid profile, reduction in exercise capacity and abnormalities in cardiac function (12, 13). Whether in childhood GHD has a different pathophysiology, in adulthood it is due to a pituitary tumor in the large majority of cases (14). In adult GHD patients, therefore, some degree of pituitary insufficiency occurs together with GHD, and combined folliclestimulating hormone (FSH) and luteinizing hormone (LH) deficiency causing hypogonadism is a rather frequent event (15).

This open transversal study was designed in order to investigate prostate volume and structural impairment, by means of transrectal ultrasonography (TRUS), pituitary, androgen and prostate hormones concentrations in adult patients who acquired GHD in adulthood. The impact of combined testosterone and GH deficiency was also investigated.

\section{Subjects and methods}

\section{Subjects}

Thirty men, aged $22-72$ years $(54.3 \pm 2.5$ years, mean \pm s.E.M.) with pituitary tumors and 30 healthy men aged $26-74$ years $(52.9 \pm 2.3$ years $)$ were enrolled in this study, free of previous or present prostate diseases and not under replacement treatment with $\alpha$-adrenergic antagonists or anti-androgen drugs. None of them had previously experienced any episode suggesting prostate and/or urethral disorders, such as prostatitis, orchitis, inflammation of seminal vesicles, spontaneous or precipitated acute urinary retention. The study was performed after approval of local Ethical Committee. All patients and controls gave their informed consent to participate in the study. All subjects were tested with the combined arginine (ARG) plus GH-releasing hormone $(\mathrm{GHRH})$ test $(\mathrm{ARG}+\mathrm{GHRH})$. According to recent studies (16-18), a GH response to ARG+GHRH below $9 \mu \mathrm{g} / \mathrm{l}$ is considered diagnostic of GHD. Among the 30 patients, 23 were diagnosed to have a very severe GHD (GH peak $<3 \mu \mathrm{g} / \mathrm{l}$ ) while seven other patients had a severe GHD (GH peak 3.1-9 $\mu \mathrm{g} / \mathrm{l})$ (16-18). Table 1 shows anthropometric and endocrine data of the 30 GHD patients at study entry. All patients, but one with a macroprolactinoma only treated with cabergoline (no. 10, Table 1), had been previously operated on via trans-sphenoidal and/or trans-cranic route for $\mathrm{GH}$-secreting, prolactin (PRL)-secreting, non-functioning pituitary adenoma or craniopharyngioma and eight of them had been irradiated. Twenty patients had panhypopituitarism, seven patients had FSH/LH and TSH deficiency, and three patients had GHD alone. Hormone replacement therapy with L-thyroxine $(50-100 \mu \mathrm{g}$ p.o. daily), cortisone acetate $(25-37.5 \mathrm{mg} /$ day $)$, was given where appropriate. Thirteen patients with hypogonadism were treated with testosterone enanthate $(250 \mathrm{mg}$ i.m. monthly) for 0.5-10 years prior to entering the study, 13 patients had hypogonadism at study entry while the remaining four had normal testosterone levels (Table 1). Adequacy of hormone replacement therapy was periodically assessed by serum-free thyroid hormones, testosterone, urinary-free cortisol and serum and urinary $\mathrm{Na}^{+}$and $\mathrm{K}^{+}$measurements. None of the patients had ever received $\mathrm{GH}$ treatment. In patients receiving testosterone replacement, hormone levels were assessed within 1 week before the next injection. In order to avoid overestimation, the duration of the disease was calculated from the time of diagnosis and 
Table 1 Patients' profile at study entry.

\begin{tabular}{|c|c|c|c|c|c|c|c|c|c|c|}
\hline $\begin{array}{l}\text { Patients' } \\
\text { age (years) }\end{array}$ & Diagnosis & $\begin{array}{c}\text { Disease } \\
\text { duration } \\
\text { (years) }\end{array}$ & $\begin{array}{c}\text { GH peak after } \\
\text { ARG }+ \text { GHRH } \\
\text { test }(\mu \mathrm{g} / \mathrm{l})\end{array}$ & $\begin{array}{l}\text { IGF-I } \\
\text { levels } \\
(\mu \mathrm{g} / \mathrm{l})\end{array}$ & $\begin{array}{l}\text { IGFBP-3 } \\
\text { levels } \\
\text { (mg/l) }\end{array}$ & $\begin{array}{c}\text { Testosterone } \\
\text { levels } \\
(\mathrm{nmol} / \mathrm{l})\end{array}$ & $\begin{array}{c}\text { DHT } \\
\text { levels } \\
\text { (nmol/l) }\end{array}$ & $\begin{array}{c}\text { PSA } \\
\text { levels } \\
(\mu \mathrm{g} / \mathrm{l})\end{array}$ & $\begin{array}{c}\text { f-PSA } \\
\text { levels } \\
(\mu \mathrm{g} / \mathrm{l})\end{array}$ & $\begin{array}{c}\text { PSA } \\
\text { density }\end{array}$ \\
\hline \multicolumn{11}{|c|}{ GHD and hypogonadism } \\
\hline 1. 22 & PRL-secreting adenoma & 10 & 1.5 & 161 & 1.7 & 3.5 & 0.2 & 0.5 & 0.1 & 0.04 \\
\hline 2. 32 & GH-secreting adenoma & 8 & 1.9 & 392 & 3.1 & 2.8 & 0.3 & 0.78 & 0.18 & 0.05 \\
\hline 3. 45 & $\mathrm{GH}$-secreting adenoma & 10 & 0.2 & 92 & 2.4 & 3.1 & 0.1 & 0.8 & 0.22 & 0.04 \\
\hline 4. 51 & NF adenoma & 2 & 5.9 & 78 & 2 & 1.3 & 0.1 & 2.2 & 0.7 & 0.17 \\
\hline 5. 56 & NF adenoma & $1 \overline{1}$ & 1.2 & 40 & 1.5 & 3.1 & 0.3 & 1.8 & 0.5 & 0.16 \\
\hline 6. 59 & NF adenoma & 1 & 1.6 & 69 & 1.4 & 2.8 & 0.2 & 1.98 & 0.3 & 0.22 \\
\hline 7. 60 & $\mathrm{GH}$-secreting adenoma & 5 & 0.1 & 100 & 2.2 & 3.1 & 0.4 & 0.3 & 0.2 & 0.02 \\
\hline 8. 61 & Craniopharyngioma & 10 & 0.1 & 98 & 1.9 & 2.8 & 0.4 & 0.3 & 0.2 & 0.03 \\
\hline 9.61 & Craniopharyngioma & 10 & 0.5 & 105 & 1.9 & 3.5 & 0.4 & 0.3 & 0.2 & 0.03 \\
\hline 10. 67 & PRL-secreting adenoma & 3 & 2.5 & 109 & 2 & 10.4 & 0.6 & 5.6 & 0.3 & 0.47 \\
\hline 11. 70 & NF adenoma & 1 & 0.1 & 53 & 1.8 & 1.0 & 0.1 & 0.01 & 0.01 & 0.0002 \\
\hline 12. 71 & NF adenoma & 8 & 1.5 & 105 & 2 & 10.4 & 0.6 & 1.6 & 0.3 & 0.1 \\
\hline 13. 72 & NF adenoma & 25 & 3.4 & 33 & 1.5 & 0.3 & 0.2 & 0.2 & 0.5 & 0.01 \\
\hline \multicolumn{11}{|c|}{ GHD and eugonadism } \\
\hline 14. 32 & Craniopharyngioma & 3 & 0.6 & 136 & 1.7 & 26.3 & 0.9 & 0.6 & 0.2 & 0.03 \\
\hline 15. 35 & NF adenoma & 1 & 0.1 & 69 & 1.8 & 22.5 & 0.9 & 0.9 & 0.4 & 0.06 \\
\hline 16. 40 & NF adenoma & 5 & 0.5 & 56 & 2 & 13.5 & 0.5 & 0.96 & 0.49 & 0.04 \\
\hline 17. 42 & NF adenoma & 1 & 0.1 & 68 & 1.8 & 34.0 & 1.3 & 0.9 & 0.4 & 0.05 \\
\hline 18. 42 & Craniopharyngioma & 5 & 0.5 & 55 & 2 & 17.0 & 0.7 & 0.96 & 0.49 & 0.07 \\
\hline 19. 44 & $\mathrm{GH}$-secreting adenoma & 10 & 0.8 & 115 & 2.2 & 15.9 & 1.2 & 1 & 0.29 & 0.05 \\
\hline 20. 45 & NF adenoma & 4 & 5.3 & 22 & 1 & 32.6 & 1 & 1.9 & 0.6 & 0.06 \\
\hline 21.50 & NF adenoma & 5 & 7.4 & 120 & 1.5 & 13.5 & 0.6 & 2.4 & 0.5 & 0.1 \\
\hline 22. 53 & NF adenoma & 4 & 8.4 & 118 & 1.5 & 13.5 & 0.6 & 2.4 & 0.5 & 0.08 \\
\hline 23. 58 & NF adenoma & 3 & 8.3 & 110 & 1 & 25.3 & 1 & 1.9 & 0.6 & 0.06 \\
\hline 24. 60 & Craniopharyngioma & 20 & 0.1 & 22 & 2.4 & 18.7 & 0.9 & 0.5 & 0.12 & 0.02 \\
\hline 25. 60 & NF adenoma & 15 & 1.1 & 58 & 1.9 & 21.8 & 1.1 & 1.5 & 0.3 & 0.07 \\
\hline 26. 64 & NF adenoma & 3 & 0.6 & 89 & 1.2 & 17.0 & 0.5 & 3.8 & 0.6 & 0.11 \\
\hline 27.67 & $\mathrm{GH}$-secreting adenoma & 6 & 0.8 & 164 & 3.1 & 15.9 & 0.7 & 6 & 0.3 & 0.3 \\
\hline 28. 67 & $\mathrm{GH}$-secreting adenoma & 16 & 2.4 & 231 & 2.8 & 20.1 & 0.8 & 0.5 & 0.1 & 0.03 \\
\hline 29. 69 & NF adenoma & 8 & 2.2 & 208 & 2.3 & 20.5 & 0.9 & 0.15 & 0.1 & 0.01 \\
\hline 30.70 & NF adenoma & 4 & 8.4 & 118 & 1.5 & 13.5 & 0.6 & 2.4 & 0.5 & 0.06 \\
\hline
\end{tabular}

GHD, GH deficiency; NF, non-functioning; DHT, dihydrotestosterone.

Reference values: IGF-I = 100-502, 100-303 and 78-258 $\mu$ g/l for patients aged 20-40, 41-60 and >60 years, respectively; IGFBP$3=1.7-7.6,2.1-4.3$ and $2-4 \mathrm{mg} / \mathrm{l}$ for patients aged $20-40,41-60$ and $>60$ years, respectively; testosterone $=12.1-21.3 \mathrm{nmol} / \mathrm{l}$; $\mathrm{DHT}=0.4-1.6 \mathrm{nmol} / \mathrm{l} ; \mathrm{PSA}=0-4 \mu \mathrm{g} / \mathrm{l} ; \mathrm{f}-\mathrm{PSA}=0.05-0.25 \mu \mathrm{g} / \mathrm{l} ; \mathrm{PSA}$ density $<0.15$.

the retrospective evaluation of symptoms presumably related to the pituitary disease was not considered. In this group the average disease duration was $7.3 \pm 1.1$ years.

Seven GHD patients and eight controls were mild smokers; none in either of the two groups was a heavy alcohol drinker and all had a normal diet intake.

\section{Study design}

The study protocol included hormonal tests performed by using commercially available kits, and subsequently prostate TRUS. ARG (arginine hydrochloride, Damor, Naples, Italy) was administered at the dose of $0.5 \mathrm{~g} / \mathrm{kg}$, up to a maximal dose of $30 \mathrm{~g}$ slowly infused from time 0 to 30 min while GHRH (1-44), (Serono, Rome, Italy) was given at the dose of $1 \mu \mathrm{g} / \mathrm{kg}$ as i.v. bolus at $0 \mathrm{~min}$ $(17,18)$. Blood samples were taken every $15 \mathrm{~min}$ from 15 up to $90 \mathrm{~min}$. Circulating IGF-I, PRL, FSH, LH, testosterone, DHT, prostate-specific antigen (PSA), free PSA and prostate alkaline phosphetase (PAP) levels were assessed at least twice. In this study, the average value of the two assays was shown. The cut-off value of $4 \mu \mathrm{g} / \mathrm{l}$ was considered as the upper limit for PSA concentrations. The calculation of PSA density, expressed as the ratio of PSA levels/prostate volume was considered as a risk factor for prostate cancer when higher than 0.15. All assessments were age-adjusted. Serum GH levels were measured by IRMA using commercially available kits (HGH-CTK-IRMA Sorin, Saluggia, Italy). The sensitivity of the assay was $0.2 \mu \mathrm{g} / \mathrm{l}$. The intra- and inter-assay coefficients of variation $(\mathrm{CV})$ were 4.5 and $7.9 \%$ respectively. Plasma IGF-I was measured by IRMA after ethanol extraction. The sensitivity of the assay was $0.8 \mu \mathrm{g} / \mathrm{l}$. The normal IGF-I range in our laboratory was 100-502, 100-303 and 78-258 $\mu \mathrm{g} / \mathrm{l}$ for patients aged 20-40, 41-60 and over 60 years respectively. The intra-assay CV were 3.4, 3.0 and $1.5 \%$ for low, medium and high points on the standard curve respectively. The inter-assay CVs were $8.2,1.5$ and $3.7 \%$ for low, medium and high points on the standard curve respectively. Plasma IGFBP-3 
was measured by RIA after ethanol extraction. The sensitivity of the assay was $0.5 \mu \mathrm{g} / \mathrm{l}$. The intra-assay CVs were $3.9,3.2$ and $1.8 \%$ for low, medium and high points on the standard curve respectively. The inter-assay CVs were $0.6,0.5$ and $1.9 \%$ for low, medium and high points on the standard curve respectively. The normal IGFBP-3 range in our laboratory for 20-40, 41-60 and over 60year-old subjects was $2.7-7.2,2.0-4.3$ and $2-4 \mathrm{mg} / \mathrm{l}$ respectively. The kits for IGF-I and IGFBP-3 assay were purchased from Diagnostic System Laboratories Inc. (Webster, TX, USA).

\section{Transrectal ultrasonography study}

Before TRUS, all 44 subjects received a preliminary enema with $200 \mathrm{ml}$ of Sorbitole and a digital rectal exploration. TRUS was performed by means of an Esaote AU5 harmonic EPI and a 5-6-7.5 $\mathrm{MHz}$ biconvex (Esaote, Genoa, Italy) transrectal transducer with Power Echo color Doppler (PECD) module to display prostate angiographic micromaps $(19,20)$. The transducer, preliminarily covered with ultrasound transmission gel (Acquasonic, Parker Lab., NJ, USA) and a disposable rubber sheath, was lubricated and gradually inserted about $3 \mathrm{~cm}$ into the rectum, then directed towards the anterior rectal wall. The prostate examination covered the antero-posterior (APD), transversal (TD) and cranio-caudal (CCD) diameters; the transitional zone; the morphology of boundaries; the occurrence of calcifications and nodules; the evaluation of seminal vesicles and of inflammatory events not previously reported by the patients. The volume of the prostate (PV) and of the transitional zone (TZV) was calculated by means of the standard ellipsoid formula $(0.52 \times \mathrm{APD} \times \mathrm{TD} \times \mathrm{CCD})$. Echo-guided prostate biopsies with power Doppler enhancement were performed if clinical or hormonal conditions required it. All scans were performed by the same investigator (SS), blind in respect to subject examinations. Prostate hyperplasia $(\mathrm{PH})$ was considered for PV exceeding $30 \mathrm{ml}$, in line with the accepted criteria for $\mathrm{BPH}(21,22)$.

\section{Statistical analysis}

Data are reported as mean \pm S.E.M. The statistical analysis was performed by means of Graph Pad package using ANOVA. Analysis was performed by means of paired and unpaired $t$-test applying the Bonferroni's correction. Linear correlation analysis was carried out, calculating the Pearson's coefficient, to assess the relationship among different parameters. Stepwise multiple linear regression was performed by SPSS Inc. (Cary, NC, USA) package to evaluate the relative importance of age, GH, IGF-I, IFGPB-3, testosterone and DHT levels on PV, TZV, prostate diameters. The $\chi^{2}$ test was also applied where appropriate. A $P$ value of less than 0.05 was considered statistically significant.

\section{Results}

\section{Hormonal data}

Individual data of GHD patients are shown in Table 1 while the comparison between GHD patients and controls is shown in Table 2. Compared with controls, GH peak after ARG+GHRH $(P<0.0001)$, IGF-I $(P<0.0001)$ and IGFBP-3 $(P<0.0001)$ levels were significantly reduced in GHD patients (Table 2). Testosterone and DHT levels were below the normal range in 13 and 10 patients respectively, while they were normal in the remaining 17 patients (Table 1). No difference was found in disease duration between eugonadal and hypogonadal GHD patients (Table 2). At study entry, plasma IGF-I levels were below the ageadjusted normal range in 6 of the 13 hypogonadal patients and 7 of the 17 eugonadal patients (Table 1). No difference in PSA levels and PSA density was found between GHD patients, either eugonadal or hypogonadal, and controls (Tables 1 and 2). Plasma f-PSA levels were significantly higher in eugonadal GHD patients $(0.4 \pm 0.04 \mu \mathrm{g} / \mathrm{l})$ than in controls $(0.2 \pm 0.03 \mu \mathrm{g} / \mathrm{l}$, $P<0.01$ ). High PSA, free-PSA (f-PSA) and PSA density levels were found in 2,20 and 7 patients respectively (Table 1). Eight controls had elevated f-PSA levels (data not shown).

\section{Prostate dimensions (Table 2)}

No difference was found by TRUS in APD and TZV among groups, while in hypogonadal and eugonadal GHD patients both TD and CCD, and consequently PV, were significantly reduced compared with controls (Table 2). PH $(>30 \mathrm{ml})$ was found in 13 controls (43.3\%), two hypogonadal (15.3\%) and three eugonadal GHD patients (5.8\%) (Fig. 1), thus the prevalence of $\mathrm{PH}$ was significantly lower in hypogonadal and eugonadal GHD patients than in controls $\left(\chi^{2}=6.90\right.$, $P=0.005)$. The transitional zone was not detectable in three GHD, two hypo- and one eugonadal, patients and in four controls. When prostate dimensions were analyzed considering the presence or absence of IGF-I deficiency, no difference in APD, TD, CCD, TZV or PV was found between patients with normal or deficient IGF-I levels both in the hypogonadal group and in the eugonadal group (Fig. 2). In contrast, when prostate dimensions were analyzed in line with age below or above 60 years, young (aged below 60 years) hypogonadal GHD patients had the lowest PV and TZV levels while no difference was found between controls and eugonadal GHD patients (Fig. 3). In addition, a significantly higher PV, but not TZV, was found in elderly controls (aged above 60 years) than in age-matched hypogonadal and eugonadal GHD patients, without any difference between them (Fig. 3). In addition, f-PSA levels were significantly lower in young controls than age-matched hypogonadal and eugonadal GHD patients $(0.15 \pm 0.02$ vs $0.33 \pm 0.09$ and $0.44 \pm 0.04 \mu \mathrm{g} / \mathrm{l}$, 
Table 2 Endocrine and ultrasonographic findings (expressed as mean \pm S.E.M.) in control subjects and in hypogonadal and eugonadal GHD patients.

\begin{tabular}{|c|c|c|c|c|}
\hline & \multirow[b]{2}{*}{$\begin{array}{l}\text { Controls } \\
(n=30)\end{array}$} & \multicolumn{2}{|c|}{ GHD patients } & \multirow[b]{2}{*}{$\boldsymbol{P}$} \\
\hline & & $\begin{array}{l}\text { Hypogonadal } \\
\quad(n=13)\end{array}$ & $\begin{array}{l}\text { Eugonadal } \\
(n=17)\end{array}$ & \\
\hline $\begin{array}{l}\text { Age range (years) } \\
\text { Age, mean } \pm \text { S.E.M. } \\
\text { Disease duration (years) }\end{array}$ & $\begin{array}{c}26-74 \\
52.9 \pm 2.3 \\
-\end{array}$ & $\begin{aligned} & 22-72 \\
& 56.1 \pm 4.2 \\
& 8.2 \pm 1.7\end{aligned}$ & $\begin{array}{r}32-70 \\
52.8 \pm 3.0 \\
6.6 \pm 1.3\end{array}$ & $\begin{array}{l}0.7 \\
0.5\end{array}$ \\
\hline $\begin{array}{l}\text { GH peak after ARG + GHRH }(\mu \mathrm{g} / \mathrm{l}) \\
\text { IGF-1 }(\mu \mathrm{g} / \mathrm{l}) \\
\text { IGFBP-3 }(\mathrm{mg} / \mathrm{l}) \\
\text { Testosterone }(\mathrm{nmol} / \mathrm{l}) \\
\text { DHT }(\mathrm{nmol} / \mathrm{l})\end{array}$ & $\begin{aligned} 34.2 & \pm 2.2^{*} \\
204.2 & \pm 7.9^{*} \\
3.3 & \pm 0.2^{*} \\
21.1 & \pm 0.7 \\
0.98 & \pm 0.05\end{aligned}$ & $\begin{aligned} 1.6 & \pm 0.4 \\
110.4 & \pm 25.2 \\
1.9 & \pm 0.1 \\
3.8 & \pm 1.0^{\star \star} \\
0.29 & \pm 0.05^{\star *}\end{aligned}$ & $\begin{aligned} 2.8 & \pm 0.8 \\
103.5 & \pm 14.3 \\
1.9 & \pm 0.1 \\
19.8 & \pm 1.4 \\
0.83 & \pm 0.06\end{aligned}$ & $\begin{array}{l}0.0001 \\
0.0001 \\
0.0001 \\
0.0001 \\
0.0001\end{array}$ \\
\hline $\begin{array}{l}\text { PSA }(\mu \mathrm{g} / \mathrm{l}) \\
\text { f-PSA }(\mu \mathrm{g} / \mathrm{l}) \\
\text { PSA density } \\
\text { PAP (U/l) }\end{array}$ & $\begin{aligned} 1.5 & \pm 0.1 \\
0.2 & \pm 0.03 \\
0.06 & \pm 0.005 \\
1.4 & \pm 0.4\end{aligned}$ & $\begin{aligned} 1.6 & \pm 0.4 \\
0.3 & \pm 0.06 \\
0.11 & \pm 0.03 \\
1.5 & \pm 0.1\end{aligned}$ & $\begin{aligned} 1.7 & \pm 0.3 \\
0.4 & \pm 0.04^{\star * *} \\
0.075 & \pm 0.02 \\
1.5 & \pm 0.5\end{aligned}$ & $\begin{array}{l}0.8 \\
0.005 \\
0.06 \\
0.8\end{array}$ \\
\hline $\begin{array}{l}\text { APD }(\mathrm{mm}) \\
\operatorname{TD}(\mathrm{mm}) \\
\operatorname{CCD}(\mathrm{mm}) \\
\operatorname{TZV}(\mathrm{ml}) \\
\operatorname{PV}(\mathrm{ml})\end{array}$ & $\begin{array}{l}32.6 \pm 1.3 \\
37.8 \pm 1.0^{\star} \\
39.8 \pm 1.0^{*} \\
2.8 \pm 0.4 \\
25.7 \pm 1.5^{\star}\end{array}$ & $\begin{array}{r}33.2 \pm 3.0 \\
30.6 \pm 2.1 \\
34.0 \pm 1.3 \\
4.2 \pm 1.1 \\
18.2 \pm 3.0\end{array}$ & $\begin{array}{r}38.0 \pm 2.4 \\
32.0 \pm 1.7 \\
36.0 \pm 0.6 \\
4.3 \pm 0.7 \\
22.3 \pm 1.6\end{array}$ & $\begin{array}{l}0.1 \\
0.001 \\
0.0006 \\
0.4 \\
0.03\end{array}$ \\
\hline
\end{tabular}

Reference values: IGF-I $=100-502,100-303$ and $78-258 \mu \mathrm{g} / \mathrm{l}$ for patients aged $20-40,41-60$ and over 60 years, respectively; testosterone $=12.1-21.3 \mathrm{nmol} / \mathrm{l} ; \mathrm{DHT}=0.4-1.6 \mathrm{nmol} / \mathrm{l} ; \mathrm{PSA}=0-4 \mu \mathrm{g} / \mathrm{l} ; \mathrm{f}-\mathrm{PSA}=0.05-0.25 \mu \mathrm{g} / \mathrm{l} ; \mathrm{PSA}$ density $<0.15 ; \mathrm{PAP}=0-2.6 \mathrm{U} / \mathrm{l}$. *significant vs hypogonadal and eugonadal patients; ${ }^{* *}$ significant vs controls and eugonadal patients; ${ }^{* \star *}$ significant vs controls. For $P$ values see the text.

$P<0.05$ and $<0.001$ respectively), and PSA density was significantly higher in young hypogonadal GHD patients than in age-matched controls and eugonadal GHD patients $(0.11 \pm 0.03$ vs $0.06 \pm 0.006$ and $0.06 \pm$ $0.006, P<0.05)$. No difference was found in PSA levels between young and elderly subjects among groups, and in f-PSA levels and PSA density in elderly subjects among groups.

\section{Prostate features}

No abnormality of prostate structure was detected in 13 patients $(43.3 \%)$ and in 15 controls (50\%).
Calcifications were detected in 15 GHD patients (50\%) (five hypo- and ten eugonadal), and eight controls $(26.6 \%)\left(\chi^{2}=4.74, P=0.09\right)$. Cysts were found in six patients $(20 \%)$, (two hypo- and four eugonadal) and four controls $(13.3 \%)\left(\chi^{2}=0.83, P=0.7\right)$. Echoic signs suggesting a condition of vesicles inflammation, were observed in three eugonadal patients $(10 \%)$ and no controls, while a prostate nodule was detected in one hypogonadal patient (no. 10, Table 1). At echo-guided needle aspiration cytological examination, nodular fibro-adenomatous hyperplasia was found. Sextant biopsies of the prostate were performed in six other patients due to elevation of PSA levels and/or PSA

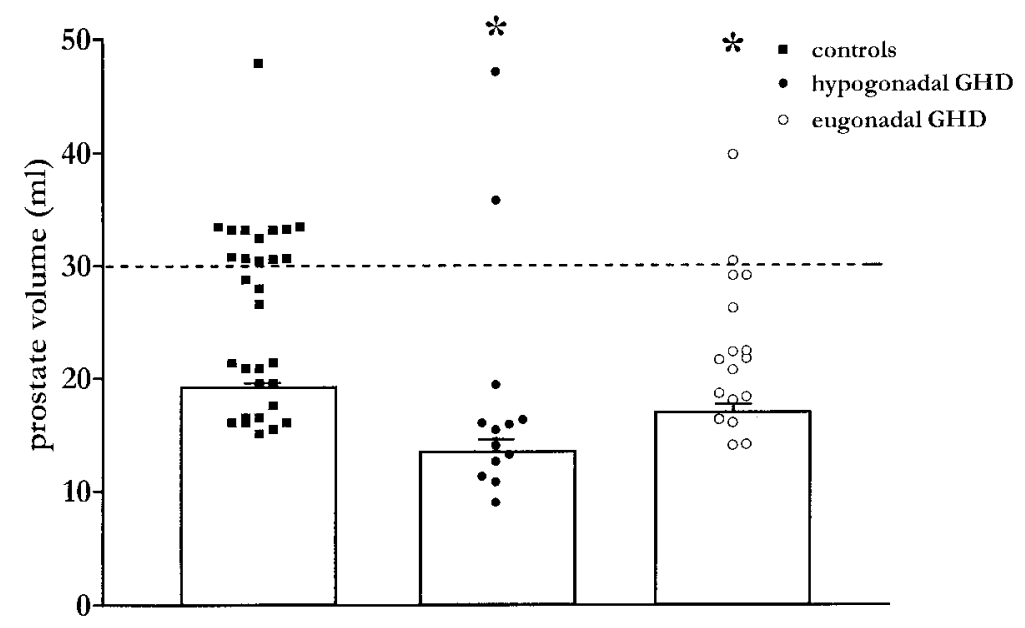

Figure 1 Prostate volume (analytical and mean values) in controls, hypogonadal and eugonadal GHD patients. The dashed line represents the cut-off value for prostate hyperplasia. Error bars represent means \pm S.E.M. ${ }^{\star} P<0.01$ vs controls. 

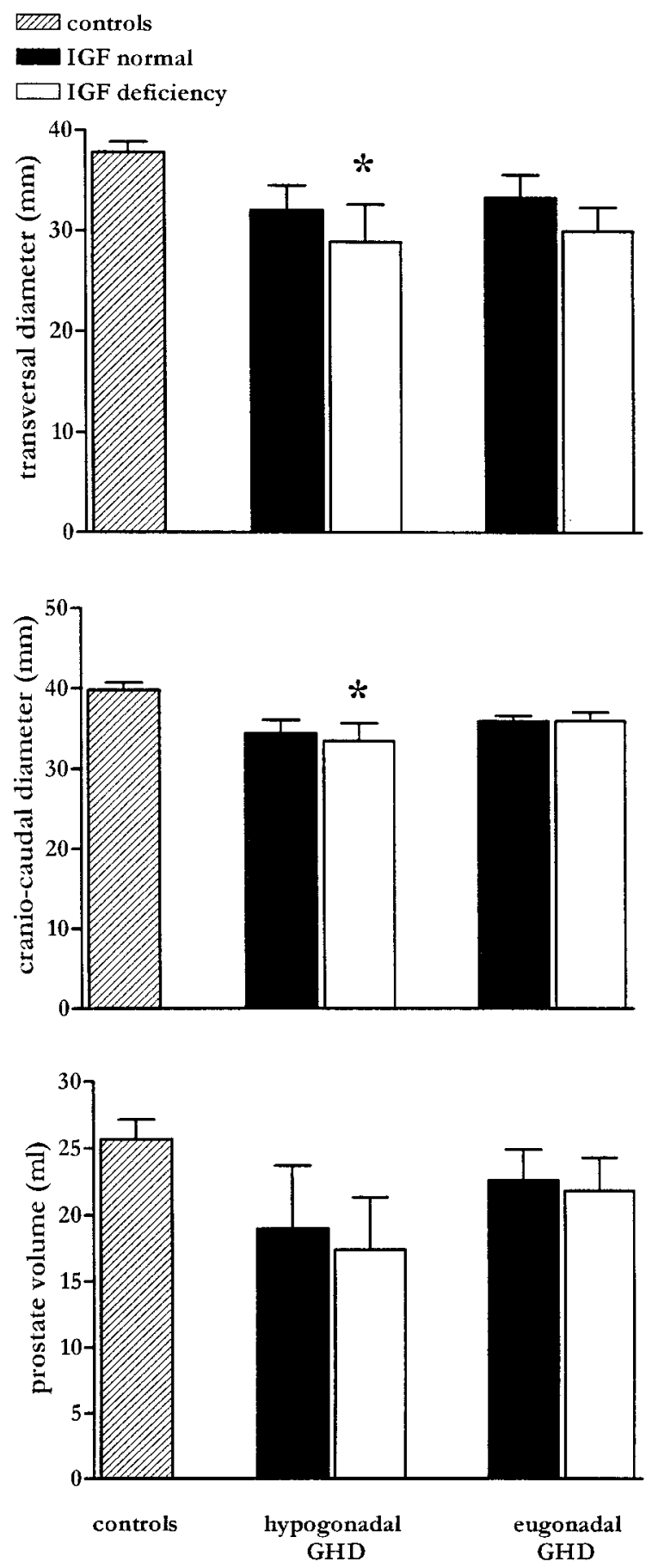

Figure 2 Prostate transversal diameter (top), cranio-caudal diameter (middle) and volume (bottom) in controls, hypogonadal and eugonadal GHD patients grouped in line with normal or deficient IGF-I levels. Error bars represent means \pm S.E.M. ${ }^{*}$ Significant $(P<0.01)$ vs controls.

density. Prostate cancer was found in none of them. The prevalence of structural prostate abnormalities, such as calcifications, cysts and nodules, was similar in patients $(56.7 \%)$ and controls $(50 \%)\left(\chi^{2}=0.067, P=0.79\right)$.
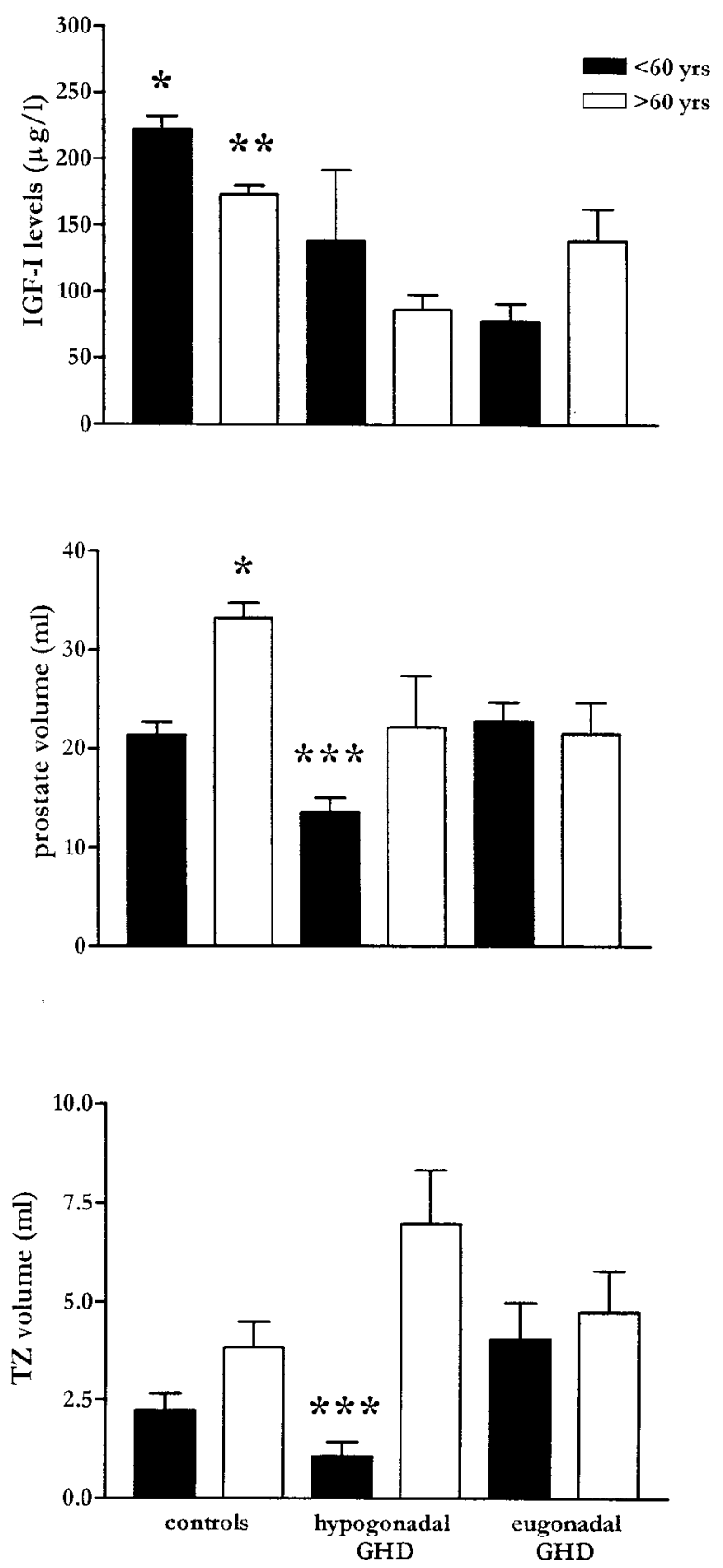

Figure 3 Serum IGF-I levels (top), prostate volume (middle) and transitional zone (TZ) volume (bottom) in controls, hypogonadal and eugonadal GHD patients subdivided in line with age. Error bars represent means \pm S.E.M. ${ }^{*}$ Significant $(P<0.005)$ vs agematched hypogonadal and eugonadal GHD patients; ${ }^{*}$ significant $(P<0.01)$ vs age-matched hypogonadal GHD patients;

${ }^{\star * *}$ significant $(P<0.05)$ vs age-matched controls and eugonadal GHD patients.

\section{Correlation analysis}

The results of the correlation analysis are shown in Table 3 . Both in controls and in GHD patients, PV and TZV were correlated to each other $(r=65, P<0.0001$ 
Table 3 Results of regression analysis.

\begin{tabular}{|c|c|c|c|}
\hline Independent variable & Dependent variable & $r$ & $\boldsymbol{P}$ \\
\hline \multicolumn{4}{|l|}{ Controls } \\
\hline \multirow[t]{8}{*}{ Prostate volume } & Age & 0.823 & $<0.0001$ \\
\hline & Peak GH & -0.474 & 0.008 \\
\hline & IGF-I levels & -0.607 & $<0.0001$ \\
\hline & IGFBP-3 levels & -0.467 & 0.009 \\
\hline & Testosterone levels & -0.080 & 0.65 \\
\hline & DHT levels & 0.167 & 0.37 \\
\hline & PSA levels & 0.407 & 0.025 \\
\hline & f-PSA & 0.467 & 0.009 \\
\hline \multirow[t]{8}{*}{ Transitional zone volume } & Age & 0.515 & 0.004 \\
\hline & Peak GH & -0.288 & 0.12 \\
\hline & IGF-I levels & -0.192 & 0.31 \\
\hline & IGFBP-3 levels & -0.238 & 0.21 \\
\hline & Testosterone levels & -0.054 & 0.77 \\
\hline & DHT levels & 0.545 & 0.002 \\
\hline & PSA levels & 0.589 & 0.001 \\
\hline & f-PSA & 0.404 & 0.027 \\
\hline \multicolumn{4}{|l|}{ GHD patients } \\
\hline \multirow[t]{9}{*}{ Prostate volume } & Age & 0.216 & 0.251 \\
\hline & Peak GH & 0.431 & 0.018 \\
\hline & IGF-I levels & -0.081 & 0.672 \\
\hline & IGFBP-3 levels & -0.169 & 0.371 \\
\hline & Testosterone levels & 0.234 & 0.214 \\
\hline & DHT levels & 0.201 & 0.287 \\
\hline & PSA levels & 0.367 & 0.046 \\
\hline & f-PSA & 0.053 & 0.779 \\
\hline & Disease duration & -0.273 & 0.144 \\
\hline \multirow{9}{*}{ Transitional zone volume } & Age & 0.454 & 0.012 \\
\hline & Peak GH & 0.226 & 0.231 \\
\hline & IGF-I levels & -0.099 & 0.602 \\
\hline & IGFBP-3 levels & -0.280 & 0.135 \\
\hline & Testosterone levels & 0.001 & 0.995 \\
\hline & DHT levels & -0.029 & 0.879 \\
\hline & PSA levels & 0.591 & 0.01 \\
\hline & f-PSA & 0.166 & 0.380 \\
\hline & Disease duration & -0.287 & 0.124 \\
\hline
\end{tabular}

and $r=0.52, P=0.003$ respectively). At the multistep analysis, in control subjects age was the strongest predictor of $\mathrm{PV}(t=7.658, P<0.001)$, while PSA and DHT levels were the strongest predictors of TZV $(t=7.234, \quad P<0.001$ and $t=3.535, \quad P=0.002$ respectively). In GHD patients, the $\mathrm{GH}$ peak after ARG + GHRH was the strongest predictor of PV $(t=2.525, P=0.018)$, and PSA levels were the strongest predictors of TZV $(t=3.876, P=0.001)$.

\section{Discussion}

The results of this study demonstrate that PV was significantly decreased both in hypogonadal and eugonadal GHD adult patients, without any difference between them, accounting for a reduced prevalence of $\mathrm{PH}$ in GHD patients than in controls. Conversely, the prevalence of structural prostate abnormalities was similar in GHD patients, either hypogonadal or eugonadal, and controls.

Androgen deprivation, by castration or pharmacotherapy, notoriously causes impairment of prostate growth (1). Androgen level seems also to modify the number, but not the affinity, of IGF-I receptors on prostate epithelium. In fact, an increase in the number of IGF-I type I receptors was demonstrated in cell cultures from patients with $\mathrm{BPH}$ after testicular suppression by gonadotropin-releasing hormone (GnRH) analogues (9). Moreover, whether prior to GnRH analogue treatment IGF-I type I receptors were found in the basal layer of prostatic epithelium, during androgen deprivation these receptors appeared also in the secretory cells, which are preferentially damaged by castration (23). Evidence is accumulating that IGFs are involved in prostate cell proliferation (24): IGF-I acts as mitogen on primary cultures of prostatic cells (25), prostatic epithelial cells produce IGFBPs (26), found also in tissues from patients with $\mathrm{BPH}$ (25). Whether chronic GH and/or IGF-I deficiency plays any role on prostate size and structure is still unknown.

In order to investigate the role played by GH and IGF-I on prostate growth and disease we designed this study enrolling adult patients with hypopituitarism. In the majority of adult patients with GHD, other pituitary hormone deficiency may occur, being FSH and LH 
deficiency the most frequently associated hormone defect $(14,15)$. As testosterone and DHT are the main stimulator factors of prostate growth and disease, GHD patients were studied separately in line with presence or absence of concomitant hypogonadism. A significant decrease in $\mathrm{PV}$ was observed in patients with GHD, mostly in those with combined GH and testosterone deficiency, but a slight significant decrease in PV was also observed in patients with normal androgen levels at the time of the study. It should be considered that the majority of the patients included in the eugonadal GHD group were under testosterone replacement, and the possibility that the hypogonadism they had suffered from for several years could have affected prostate size is highly likely. On the other hand, no difference in PV was found between controls and eugonadal GHD patients aged below 60 years, who had significantly higher volumes of both the entire prostate and the transitional zone than young hypogonadal GHD patients. Elderly controls had significantly higher PV, but not TZV, than both hypogonadal and eugonadal GHD patients, indicating that a prolonged state of GH and/or IGF-I deficiency either or not combined with androgen deficiency is necessary before a reduction in prostate size can be documented. The results of prostate size, but not structure, in GHD patients paralleled the known decrease in other organs such as the heart (27). However, no difference in the abnormalities of prostate structure was found between controls and patients, being calcifications detected in $26.6 \%$ and $50 \%$; cysts in $13.3 \%$ and $20 \%$, vesicles impairment and/or benign nodules were found in $13.3 \%$ of patients and none of controls. A trend to an increased prevalence of calcifications was observed in eugonadal GHD patients (58.8\%) either when compared with hypogonadal GHD patients $(34.8 \%)$ and to controls $(26.6 \%)$, although it did not attain statistical significance. Whether this could be due to androgen replacement can not be ruled out.

IGFBP-2 and IGFBP-3, circulating carriers of IGF-I, can be cleaved by the PSA contained in the seminal plasma, so increasing the intra-prostatic concentration of IGF-I (28), and, as shown by in vitro studies, prostate cell growth is stimulated by IGF-I and inhibited by IGFBP-3 (3, 29-31). However, no significant difference in IGFBP-3 levels was found between hypogonadal and eugonadal patients and in both GHD groups IGFBP-3 levels were significantly lower than in controls. Although the model of GHD in humans is perhaps not the best method to investigate in vivo the effect of the GH/IGF-I axis on the prostate as in these patients both IGF-I and IGFBP-3 are low, no difference was found in prostate volume and diameters between patients with normal or abnormally low IGF-I levels. It should be noted, however, that even patients with normal IGF-I levels had their values in the low to normal range. However, in our controls a strong inverse correlation was found between IGF-I and IGFBP-3 levels and PV.
In conclusion, the results of the present study show that longstanding GH and/or IGF-I deficiency induced a decrease in prostate size mostly in patients with concomitant testosterone deficiency. It is intriguing that in contrast with acromegaly, where prostate volume increased with aging even with low androgens levels, in GHD patients prostate volume did not correlate with age, as in controls, even in presence of normal androgen levels.

\section{References}

1 Cunha GR, Donjacour AA, Cooke PS, Mee S, Bigsby RM, Higgins SJ et al. The endocrinology and developmental biology of the prostate. Endocrine Reviews 19878 338-362.

2 Morgentaler A, Bruning CO III \& DeWolf WC. Occult prostate cancer in men with low serum testosterone levels. Journal of American Medical Association 1996276 1904-1906.

3 Cohen P. Serum insulin-like growth factor-I levels and prostate cancer risk - interpreting the evidence. Journal of the National Cancer Institute $199890876-879$.

4 Daughaday WH. The possible autocrine/paracrine and endocrine roles of insulin-like growth factors of human tumors. Endocrinology $19901271-4$.

5 Chan JM, Stampfer MJ, Giovannucci E, Gann PH, Ma J, Wilkinson $\mathrm{P}$ et al. Plasma insulin-like growth factor-I and prostate cancer risk: a prospective study. Science 1998279 563-566.

6 Wolk A, Mantzoros CS, Andersson SO, Bergstrom R, Signorello LB, Lagiou P et al. Insulin-like growth factor 1 and prostate cancer risk: a population-based, case-control study. Journal of the National Cancer Institute $199890911-915$.

7 Grimberg A, Rajah R, Zhao H \& Cohen P. The prostatic IGF system: new levels of complexity. In Molecular Mechanisms to Regulate the Activities of Insulin-like Growth Factors, pp 205-215. Eds K Takano, N Hizuka \& SI Takahashi. Amsterdam: Elsevier, 1998.

8 Cohen P, Peehl DM, Lamson G \& Rosenfeld RG. Insulin-like growth factors (IGFs), IGF receptors and IGF binding proteins in primary cultures of prostate epithelial cells. Journal of Clinical Endocrinology and Metabolism 199173 491-497.

9 Fiorelli G, De Bellis A, Longo A, Giannini S, Natali A, Costantini A et al. Insulin-like growth factor-I receptors in human hyperplastic prostate tissue: characterization, tissue localization, and their modulation by chronic treatment with a gonadotropin-releasing hormone analog. Journal of Clinical Endocrinology and Metabolism 199172 740-746.

10 Colao A, Marzullo P, Ferone D, Spiezia S, Cerbone G, Marino Vet al. Prostate hyperplasia: an unknown feature of acromegaly. Journal of Clinical Endocrinology and Metabolism 199883 775-779.

11 Colao A. Marzullo P, Spiezia S, Ferone D, Giaccio A. Cerbone G et al. Effect of growth hormone $(\mathrm{GH})$ and insulin-like growth factor1 on prostate diseases: an ultrasonographic and endocrine study in acromegaly, GH-deficiency and healthy subjects. Journal of Clinical Endocrinology and Metabolism 199984 1986-1991.

12 De Boer H, Blok G \& van der Veen EA. Clinical aspects of growth hormone deficiency in adults. Endocrine Reviews 199516 63-86.

13 Carrol PV \& Christ ER. Growth hormone deficiency in adulthood and the effects of growth hormone replacement: a review. Journal of Clinical Endocrinology and Metabolism 199883 382-395.

14 Shalet SM, Toogood AA, Rahim A \& Brennan BMD. The diagnosis of growth hormone deficiency in children and adults. Endocrine Reviews 199819 203-223.

15 Toogood A, Beardwell CG \& Shalet SM. The severity of growth hormone deficiency in adults with pituitary disease is related to the degree of hypopituitarism. Clinical Endocrinology 199441 511-516.

16 Aimaretti G, Corneli G, Razzore P, Bellone S, Baffoni C, Arvat E et al. Comparison between insulin-induced hypoglycemia and growth hormone $(\mathrm{GH})$-releasing hormone+arginine as provocative 
tests for the diagnosis of GH deficiency in adults. Journal of Clinical Endocrinology and Metabolism 199883 1615-1618.

17 Colao A, Cerbone G, Pivonello R, Aimaretti G, Loche S, Di Somma $\mathrm{C}$ et al. The Growth Hormone $(\mathrm{GH})$ response to arginine plus $\mathrm{GH}$ releasing hormone test is correlated to the severity of lipid profile abnormalities in adult patients with GH deficiency. Journal of Clinical Endocrinology and Metabolism 199984 12771282.

18 Colao A, Di Somma C, Pivonello R, Loche S, Aimaretti G, Cerbone $\mathrm{G}$ et al. Bone loss is correlated to the severity of growth hormone $(\mathrm{GH})$ deficiency in adult patients with hypopituitarism. Journal of Clinical Endocrinology and Metabolism 1999 84 1919-1924.

19 Rubin JM, Bude RO, Carson PL, Bree RL \& Adler RS. Power Doppler US: a potentially useful alternative to mean frequencybased color Doppler US. Radiology 1994190 853-856.

20 Collins GN, Raab GM, Hehir M, King B \& Garraway WM. Reproducibility and observer variability of transrectal ultrasound measurements of prostatic volume. Ultrasound in Medicine and Biology 199521 1101-1105.

21 Berry SJ, Coffey DS, Walsh PC \& Ewing LL. The development of human benign prostatic hyperplasia with age. Journal of Urology $1984132474-479$.

22 McNeal JE. Normal histology of the prostate. American Journal of Surgical Pathology 198812 619-633.

23 Evans GS \& Chandler JA. Cell proliferation studies in the rat prostate: II. The effects of castration and androgen-induced regeneration upon basal and secretory cell proliferation. Prostate $198711339-351$.

24 Cohen P, Peehl DM, Stamey TA, Wilson KF, Clemmons DR \& Rosenfeld RG. Elevated levels of insulin-like growth factor-binding protein-2 in the serum of prostate cancer patients. Journal of Clinical Endocrinology and Metabolism 199376 1031-1035.
25 Serio M \& Fiorelli G. Dual control by androgens and peptide growth factors of prostatic growth in human benign prostatic hyperplasia. Molecular and Cellular Endocrinology 1991 78 C77-C81.

26 Russell PJ, Bennett S \& Stricker P. Growth factor involvement in progression of prostate cancer. Clinical Chemistry 199844 705-723.

27 Saccà L, Cittadini A \& Fazio S. Growth hormone and the heart. Endocrine Reviews 199415 555-573.

28 Cohen P, Graves HCB, Peehl DM, Kamarei M, Giudice LC \& Rosenfeld RG. Prostate-specific antigen (PSA) is an insulin-growth factor binding protein-3 protease found in seminal plasma. Journal of Clinical Endocrinology and Metabolism 199275 1046-1053.

29 Angelloz-Nicoud \& Binoux M. Autocrine regulation of cell proliferation by the insulin-like growth factor (IGF) and IGF binding protein-3 protease system in a human prostate carcinoma cell line (PC-3). Endocrinology 1995136 54855492.

30 Figueroa JA, Lee AV, Jackson JG \& Yee D. Proliferation of cultured human prostate cancer cells is inhibited by insulin-like growth factor (IGF) binding protein-1: evidence for an IGF-II autocrine growth loop. Journal of Clinical Endocrinology and Metabolism 1995 $803476-3482$.

31 Plymate SR, Tennant M, Birnbaum RS, Thrasher JB, Chatta G \& Ware JL. The effect on the insulin-like growth factor system in human prostate epithelial cells of immortalization and transformation by simian virus-40 $\mathrm{T}$ antigen. Journal of Clinical Endocrinology and Metabolism 199681 3709-3716.

Received 2 December 1999

Accepted 2 March 2000 